\title{
Mobility Practices and Gender Contracts: Changes in Gender Relations in Coastal Areas of Norway's High North
}

\author{
Siri Gerrard ${ }^{1}$ \\ The Arctic University of Norway, Tromsø, Norway
}

\begin{abstract}
This article addresses the relationship between gender contracts and mobility practices in fishery communities of Norway's High North, mainly Skarsvåg, Finnmark. By combining perspectives from gender research, anthropology and geography, the aim of this article is to contribute to a greater understanding of the interrelations between structural, material, and cultural changes in the context of a smallscale coastal fishing environment. My main question is whether changes in mobility practices, related to restructuring of the fisheries by means of a quota-system, Norway's agreement with the European Union (EEA) and other changes in the Norwegian context, have had impacts on gender contracts and in what way. Emphasis lies on the period after World War II and until today. The data collection are based on a lifelong engagement on gender questions in fishery villages, reading newspapers and using registers as well as interviews and participant observation through several research projects.
\end{abstract}

Keywords: Mobility, gender contracts, fishery, Norway's High North

\section{Introduction: Gender Contracts, Mobilities, and Place}

My interest in fishery and gender-related research began in the 1970s and has continued until today (Gerrard, 1975, 1983, 1995, 2008, 2011, 2013, 2015, 2016). ${ }^{2}$ It was Ina's marriage that induced me to look closely at the phenomenon of gender, gender contracts, mobility, and place. Like most other young women from fishing villages, Ina had moved away from Skarsvåg to go to school and then get a job for which she had been educated. When the time for marriage came, Ina and her future husband arranged for a Saturday morning wedding in the Skarsvåg church in which she had been baptized and confirmed. Immediately after the wedding ceremony, the couple and some of the guests drove in private cars to Alta, where they

\footnotetext{
${ }^{1}$ Corresponding author. Address: Siri Gerrard, Center for Women and Gender Research (KVINNFORSK), Postbox 6050 Langenes, 9037 Tromsø, Norway. E-mail: Siri.Gerrard@uit.no

${ }^{2}$ This article builds on Gerrard (2011) and Gerrard (2015).
} 
boarded a plane to Oslo Airport. The rest of the guests were waiting in a banquet hall for the newly wedded couple to arrive. The long travel, first 240 kilometres by road across one of Norway's northernmost island and then more than 1200 kilometres by air to a place nearby Oslo, the capital of Norway, did not seem to be an obstacle to a successful wedding celebration lasting until early Sunday morning.

This event is one example that illustrates the complexity of mobility practices. The wedding and the wedding party exemplifies perhaps "a once in a lifetime" experience, but behind the wedding event one can find a wide array of mobility practices including national emigration, immigration, and commuting practices that can be related to many sectors of life.

The main question examined in this article is how to determine the extent to which changes in mobility practices related to restructuring of the fisheries by means of a quota system and other changes of the 1990s have affected gender contracts in small-scale fishery communities or villages in Finnmark, an area of Norway's High North. This includes examining how structural, material, and cultural conditions related to mobilities have contributed to changes in local gender contracts, a concept developed and used by the Swedish geographer and Professor Gunnel Forsberg (2001).

To approach the relationship between mobility practices and gender contracts, this article draws on empirical data from Skarsvåg and other fishing communities in coastal Finnmark. Mobility practices related to fisheries, reindeer herding, and public services have 'always' taken place in Finnmark. However, this article mostly concentrates on the post-war period and the period after The Ministry of Fisheries stopped the cod fishing in 1989 and introduced the boat-quota system north of the $62^{\text {nd }}$ latitude to regulate fishing to sustain the stocks of cod, haddock and saithe in $1990 .{ }^{3}$ The introduction of the quota system ended the long tradition in which coastal fishers could take as many tonnes of cod, haddock, and saithe as they could manage and sell to a fishing plant. From that time on, the amount a fisher could catch during a year was dependent on decisions made by others. This period coincides with the introduction of the principles of New Public Management and privatization in the public sector where support to the municipality mainly is based on the number of inhabitants, resulting in financial problems for many municipalities (Hansen 2014). Some years later, in 1994, Norway together with Iceland and Lichtenstein signed the European Economic Area Agreement (EEA) with the European Union (EU)

\footnotetext{
${ }^{3}$ In 2004, the Ministry of Fisheries changed to Norwegian Ministry of Fisheries and Coastal Affairs and in October 2013, the Norwegian Ministry of Fishery and Coastal Affairs was merged with the Ministry of Trade and Industry. The quotas are determined in consultation with Russian and Norwegian marine researchers and decisions made by the Russian-Norwegian Fishery Commission, since Russia and Norway together manage the natural resources within the 200 nautical miles zone of the Barents Sea. Formal meetings and, since 2006, informal meetings with fishers, fish-workers, unions, and other organizations are arranged before final decisions on distribution of the quotas are made.
} 
that gave access to EU's Internal Market and the application of EU's four freedoms: free float of capital, goods, services and people. Since 1994, the citizens of the 31 EEA countries have many of the same rights as Norwegian citizens. They can establish themselves in Norway and for example start as fishers, following the Norwegian regulations. Another reform that took place was the expansion of compulsory education that implied more years of schooling (NOKUT n.d.). Such decisions made from outside are all agreements and reforms with implications for fisheries, fisheries villages and fishery families.

This article therefore focuses on changes in one small corner of Norway's High North dependent on fish stocks, climate and policies decided upon from outside in a specific period of time and examines the effects of these changes on gender contracts and mobility practices. This kind of research on gender and mobility included fishery does not only take place in Norway, but also in other countries, for example Canada. ${ }^{4}$ Norwegian mobility research focuses mostly on immigration, emigration, and commuting separately (Sandanger 1979; Sørlie 2005; Langørgen 2007; Engebrigtsen og Nordbert 2006; Aure 2008; Brockman and Kjeldstadli 2008; Hjorthol 2008, Munkejord 2009, 2011). However, studies that focus on Norwegian and foreign immigrants, emigrants, commuters and fishers that perform mobile work within the same localities are rather unusual. Studying mobility practices within a specific geographical site, like a fishing village, makes it possible to consider diverse forms of mobilities in relationship to each other to highlight how they relate to gender contracts in structural, material, and cultural terms. This approach is inspired by Ingrid Rudie's work (Rudie 1984; 2008). She described "practice" as "the routinization of events that people participate in," engaging social organization, experience, and "the ongoing sequence of ever-changing confrontation with new challenges" (Rudie 2008, 81). The concept mobility practices is used in this article to encompass routinized actions of people moving themselves from one place to another resulting in myriad changes depending on distances, relationships, the textures of interests, and feelings of belonging. Mobility practices can thus be understood in light of women's and men's relationships, their knowledge, various aspects of the place of which they are a part as well as different national policies. The relationships, knowledge, and feelings of belonging can be inscribed in the bodily movements as well as in the cultural baggage that women and men carry with themselves when actions such as mobility practices are performed.

\footnotetext{
${ }^{4}$ See for example: Arctic University of Norway (n.d.) and the Canadian research program On the Move Partnership (n.d). www.onthemovepartnership.ca (accessed 29.5.2017).
} 
Women and men's actions and their identity management vary with time and place (Friedman 1998). Thus, fishery and coastal communities set their marks on female and male identities and livelihoods (Gerrard 1975, 2003; Davis and Klein 1988; Porter 1993; Gerrard and Balsvik 1999; Neis et al 2005). While the concept of identity management often is related to individuals, the concept of gender contract can be especially useful in trying to understand what is going on among couples or other gendered relations within the frames of specific places. Gunnel Forsberg $(2001,161)$ defines gender contracts as the informal rules of women and men's everyday actions related to local or regional structures, but also to the cultural and social circumstances to which people relate. She emphasises that the spatial analysis of gender relations contributes to making feminism spatial as well related to patriarchy, gender regimes, and gender negotiations, and shows how they can be very dependent on various urban, agricultural, and industrial localities. ${ }^{5}$ Feminist oriented research has also demonstrated the importance of bringing the intersection between gender, class, race, ethnicity and other dividing categories into the discussion (Crenshaw 1989; Lykke 2003). Such perspectives are also relevant for studies in small fishing villages.

The informal rules that guide women's and men's actions in relation to the specific material, social, and cultural conditions of a place, or a region, focus on a person's individual, social, and organizational actions, and, in essence, deal with gender aspects of social norms. These norms can be negotiated and renegotiated particularly when there are imbalances of power or changes in circumstances surrounding gendered relationships (Forsberg 2003, 161-63). In this way, Forsberg's perspective considers women as an active partner in gender relations, thus opening up possibilities for change within the tight relationships between gender, place, and its structure and culture. This is particularly useful in studies of fishing villages, in which various kinds of power structures between women and men are well documented (Gerrard 1983, 1986, 1995, 2008, 2009; Neis 1993; Porter 1993; Munk-Madsen 1996).

\section{A Place in the High North, and Key Aspects of Traditional Gender Contracts}

Skarsvåg is one of the many small fishery villages in Finnmark. Since the 1990s when the quota-system was introduced, the filleting production stopped and the need for workers decreased. The population in the village also decreased: from 217 inhabitants in 1980 (Statistisk Sentralbyrå 1981) and

\footnotetext{
${ }^{5}$ In this approach, Forsberg builds on notions on gender and power developed by Hirdman (1988, 49-63).
} 
157 in 1990 (Statistisk Sentralbyrå 1991) to about 30-40 more or less permanent inhabitants today. ${ }^{6}$ Most of the population who lives in the village all year around consists of middle aged and elderly people. There are no households with children or youth.

Up to the 1970s, the community hosted more than 50 households with several household members plus special dormitories for the workers at the fish processing plant (Gerrard 1975). Most of today's households consist of one or two persons spread over less than 30 households. No residential houses have been constructed in this millennium. Some of the residential houses belong to the migrants, children of migrants and persons who also have houses in the municipal centre. Sami reindeer families, immigrants from abroad, and fishing tourist companies have also purchased houses sold by emigrants. Thus, many of the houses are often empty during the winter months.

The decrease of the population has also brought changes in the local and voluntary associations. They have merged into Skarsvåg Community Association (bygdelag), also including emigrants. Skarsvåg Fishermen's Association is today a part of Nordkapp Fishermen's Association including fishers from all the fishery villages in the municipality.

The changes in the population and the social organisation of the village are reflected in the materialities of the place, first and foremost due to changes in the market situation, the cod stock, and the catch of Kamchatka crabs. Kamchatka fishery is a relatively new kind of fishery that first started in the eastern part of Finnmark and has expanded further west.

The fish filleting factory with about 20-30 local and migrant workers, mostly from Norway, but also from Finland, reduced the number of employees after the fishing moratorium and then the launch of the quota system in the 1990 (Gerrard 1995). The public kindergarten closed its doors when the number of children decreased and the municipal budget deteriorated. The same happened to the school in 2012. The school building with classrooms, sport facilities, and empty swimming pool function now as a community house. Since 2004 immigrants from abroad have also bought fishing boats. Today the fish plant employs a few local workers plus some from the EU countries especially during the winter season. Other facilities consist mainly of campgrounds, a hotel with a restaurant open in the summer months, a café in combination with a souvenir shop, Julehuset, a bar in combination with a tour business, and foreign-owned tourist fishing companies.

There were between 30 and 40 fishers in Skarsvåg in the 1970s (Gerrard 1975). Now there are about 20 - about ten active registered Norwegian

${ }^{6}$ Data collected in Skarsvåg summer 2016. When nothing else is mentioned, I base data on fieldwork in 2016 and 2017. 
fishers, seven from EU countries who are formal residents in the village, and three, including a skipper, who commute from Honningsvåg, $25 \mathrm{~km}$ away. ${ }^{7}$ After the quotas were introduced, some Skarsvåg women also registered as fishers. They worked together with their husband either at sea or on land. Later also women from abroad have registered (Gerrard 2016).

There are still boats moored in the harbour, storehouses, and rooms to prepare the nets and do the other maintenance tasks needed in Skarsvåg's fishery industry. The well-established fishers who were born in Skarsvåg possess the fishery knowledge that has been transferred from generation to generation and for the youngest fishers, also from special marine related education. Annually seasonal fishers come with their boats, especially in the spring when the cod stock is on its way to the Barents Sea. The fishers deliver the catch at the local fish plant that has had many owners the last 30 years. In June 2016, Norway Seafoods, a subsidiary of Aker ASA, sold most of their fish plants to Lerøy Seafood Group, one of the largest salmon producing corporations in Norway (Nordstrøm 2016). However, the Skarsvåg plant was sold to Johan B. Larsen AS, an established fish company from Sørvågen in Lofoten islands. The Skarsvåg plant now consists of facilities of processing, receiving, weighing, packing, and sending the fish on trailers often bound for other processing plants or the fresh fish market in Europe. Good roads to the North Cape tourist area and to the municipal centre, Honningsvåg, where shops and other services are concentrated, are now open all year due to improved snow removal and political decisions. The area has also access to high-speed internet that connects the village to the world outside.

\section{Traditional Coastal Gender Contracts}

Traditionally, both women and men in fishing villages worked long hours, men as active fishers at sea and on shore to earn household cash, and women doing the household work, cooking, caring for children and elderly people, knitting, sewing, repairing clothing, and tending domestic animals. Women also helped family or neighbourhood fishers with shore tasks related to fishing, like baiting the long line, gutting fish when catches were big, washing boats at the end of the season. Some women also worked as salters in the busiest plant times. Some of these roles were gender specific work roles (Bratrein 1976; Flakstad 1984). Women were also more actively connected to the local community and were members of several community associations. Researchers termed them as "the fishing industry's ground crew or the shore crew” (Gerrard 1983; Porter 1993). Women's domestic work did not qualify them for government social benefit rights such as

\footnotetext{
${ }^{7}$ Own observations, summer 2016, but these number changes quickly.
} 
pensions, holiday allowances, or public health funding connected to employment. Their tasks were performed as a longstanding informal and silent agreement taken for granted without much discussion. The lack of social rights can be explained by the fact that the fishing households, often in combination with agriculture, were peasant households where only men's fishing was paid work (Brox 1966). The social rights, often called welfare rights were mostly connected to wages and paid work (Kuhnle 1983).

One of the consequences of these gender patterns and this unspoken gender contract was that there were more paid jobs for men than for women both in fishing and at the fish plant (Rudie 1969/70). Therefore, unless young women married and established a household after finishing seven years of schooling and staying home to help their mothers or other local women, young women often left fishery communities to find paid work or continue their education. The fact that more young women emigrated (Nyseth 1983) and men stayed behind was also a feature of the gender contract of that time, seldom problematized by young women, men, fathers, or mothers (Gerrard 1975). Many of the fishers' wives therefore came from other communities. They were in other words immigrants. Households thus settled in the husband's place of origin or where he was fishing, a form of settlement referred to as patrilocal settlement. People have recounted how whole households moved to Skarsvåg from other places because of the availability of the fish. The advantage of living close to fish stocks was that the fishers often could return home in the evening, and thus keep the household in proximity to the fishing boat (Bratrein 1976; Brox 1966). Such organizational structures formed the unit on which gender contracts were based. They were also the basis for women's and men's knowledge, experiences, and the local fishery culture. These contracts were woven into the fishery culture, silently accepted, seldom discussed or negotiated and independent of the coastal village they came from. Such contracts can also be considered as the glue in the relationship that existed between fishery work, mobility practices, and gender contracts in many coastal fishery villages.

When the fishers' wives, included women with small children from Skarsvåg and other fishing villages along the Finnmark coast, in the 1970s started to commute several times every semester during four years in order to attend higher education in order to be a teacher, they did so despite their husband's own mobile work. This form of adaptation also implied a new gender contract that in the short run implied being away from the household and the village, but in the longer run would secure paid work for wives. This form for attending higher education was made possible for those students who were mothers because the husband took over some of the 
household work, but also because other women, relatives or friends, helped caring when the husband was at sea and the wife at school. When new possibilities turned up like decentralized educational opportunities for students to live at home and attend class three to five weeks every semester, new contracts were developed.

\section{Newer Trends in Mobility Practices and Gender in Norway's High North}

Demographic research shows that during the last 25 years, both women and men emigrated from rural as well as coastal areas (Sørlie 2005), and especially when gaining higher education (Foss 2009). At the same time, immigration has taken place. Mai Camilla Munkejord (2009, 2011) found that more than half the population in Finnmark are immigrants from other municipalities in Finnmark and the rest of Norway as well as from abroad, coming there to work or to marry. Commuting has also increased, especially during the latest decades (Walsh 2016).

Particularly since the fishing quota system was introduced in the 1990s, fishers seem to have become more mobile on a daily basis. With stronger boat motors and sometimes a longer trip to go to deliver the catch, living close to the fishing fields seems to be less important compared to earlier decades. Especially since 2000, families emigrate to town centres where women can find work and high school students can live at home while the fishers commute from town to boat mooring, often to the village they had lived earlier.

Elderly women and men are also increasingly migrating to other locations. One interviewee, Kari, told me in the summer of 2007 that "Now we are also moving to Tromsø, where two of our kids live." Since 2012, at least five households with members above age 70 years migrated to urban areas to rent flats, access health care and maintain contact with friends and family members. This is a new resident and migration pattern. Until recently, elderly people stayed in their own house and migrated only when they needed care in municipal nursing homes.

Younger fishers also move away, and other fishers move in. In Skarsvåg, after many years of rather low recruitment to fisheries, six local young men, born in the late in 1980s or early 1990s, decided to go into fisheries. All have bought houses or hired flats in Honningsvåg or nearby, some of them together with their girlfriends who have their employment there. The young couples have begun a pattern of young families settling where there are workplaces for women, kindergartens, and schools. When such public facilities do not exist, younger women and men may find small villages less attractive. As a result, when they form couples, the young men move with 
the women even if they then have to commute to their boat mooring. There are also examples of people moving back to small fishery villages. One elderly woman I interviewed, resettled in Skarsvåg when her husband passed away. One of the six young fishers who migrated away from the village with his middle-aged parents some years ago moved back to the village when he became a maritime trainee. Registering as a citizen residing in Skarsvåg in the municipality of Nordkapp enabled him to fish and also to catch Kamchatka crabs, rights fishers have when they live and have fished east of the $26^{\text {th }}$ latitude close to Skarsvåg. After ending his training period, he had charge of a boat moored in Skarsvåg, then later bought his own boat and became an active coastal fisher. Another young fisher told me that when he was 19 years of age, he worked on a boat because he liked to fish, but did not think he should invest in a boat. But then the skipper and owners of the fish boat he worked on purchased a new and highly modern boat-something they would never have done unless the younger fishers had demonstrated interest in fishing. Despite these improvements, entire wellestablished as well as new households migrate away.

When active fisher families and young fishers move away to other towns, there are, as already mentioned, many examples that the men continue to fish on a boat, often his own boat that is anchored and has its port in Skarsvåg. The fishers have commuted or commute either by car, by air, or by the coastal steamer, depending on where the family has settled. Commuting from home to the boat mooring for these men is a new adaptation to small-scale fishing in Finnmark. Earlier, the local fishers lived in the fishing village where the boat belonged. An exception is the fishers that bring their boats for the season. One fisher, still living in Skarsvåg, said in 2004, "Look at Ronald and his crew. They have for several years and every morning travelled every day from their home in the municipal centre to Skarsvåg in the cod season when they are fishing with the nets. It's just the weather that could stop them, and it does not happen often". Ronald and his family had lived in Skarsvåg, but when they built a new house, they moved to the municipal centre. He and his family were pioneers in this form of commuting in Skarsvåg (Gerrard 2013). In this way the fishing village become a place for fishers and others related to fishery, while the household work is carried out in the place where the household is established. However, when Ronald bought a larger boat some years ago, his boat now is moored close to where the family lives in the municipal center.

Along the coast of Finnmark and thus in Skarsvåg, reindeer owners and herders have long maintained traditional mobility practices. In earlier days, the entire family would stay inland during the winter and migrate to live at the coast from May to September. The Sami reindeer families' commuting practices have been changing. Now the Sami male reindeer owners and 
herders accompany the reindeer from inner Finnmark to the coast in the spring, but women and children come later to the coast by car when school holidays start, and go back when school begins, unless the women have specialized in making and selling handicraft products (doudji) to tourists (Utsi 2010). Some of the herders go back to inner-Finnmark and return to the coast only when there is a need for their labour.

Emigrants also perform commuting practices. Women and men born in Skarsvåg or their children and grandchildren return more or less regularly to spend their holidays, celebrate birthdays, anniversaries, or participate in festivals and related events like Ina's wedding. There are many examples of migrate women helping organize summer festivals or other events. In the Verdens nordligste bryggefestival (The World's Northernmost Wharf Festival) of 2015, 2016 and 2017, women migrants between ages 22 and 50 took the lead. For a local village like Skarsvåg, emigrants contribute to sustain the community by helping with voluntary work and sharing the feeling of still belonging to the village.

\section{New Trends in Out-commuting}

Since fish plant work reduced its staff and the kindergarten and the school were closed, there have been few employment facilities for women in smallscale coastal villages. In order to get stable work, some women had to work in the public health, social and private service sectors. Women then commute from the fishing village to the municipal centre or to the neighbour village, which had been made possible by better roads, and even a child as young as three commuted to kindergarten with his working mother. There are also couples who do not live in the same place. In order to meet, one of them has to commute. If a man lives in Skarsvåg, he commutes to the place where his female partner lives or the woman visits her partner in Skarsvåg. This arrangement is considered to be "living apart together," (Levin 2004). Couples can meet during weekends, monthly, or during holidays, and may spend varying degrees of their everyday lives together.

Travel to and from school sites is still happening and to a greater extent than before because compulsory schooling lasts several years. This form of commuting is carried out by high school pupils and during some years, also by adult students. As already mentioned the adult education that local women performed must be understood in the light of the possibilities of living at home while attending specially organized courses during the semester. When the local school closed in 2012, the two school children who now have moved, had to commute to a school more than $25 \mathrm{~km}$ away. Similarly, in Loppa, one of the smallest coastal municipalities in Finnmark, 
both kindergarten- and school children from one of the villages commute every day by bus and ferry to the municipal centre Øksfjord. ${ }^{8}$

Another type of mobility practice related to out-commuting is exhibited by persons or families formally settled in Skarsvåg who go away to cabins or to second homes elsewhere, and commute back and forth between home and their leisure site. In Skarsvåg, several of the households have made such an adaptation and some of them have their holiday homes near the birthplace of the wife (Gerrard 2009). This means that many are away for weekends or holidays, and that much of their leisure activities are carried out elsewhere. Similarly, elderly women and men also started in the 1990s to travel to southern Europe for some weeks or months. This reflected secure incomes, but also the desire to escape to a warmer climate during the hard winter months.

In 2004, Solrun, an elderly woman who often travelled to the Mediterranean countries, described leisure travels that revealed the geographic complexities of their lives: "We both go to the south, but we must get home before the fishing season starts in the springtime. There I have participated in several courses and in the choir. My husband has attended painting courses. We've also got friends from other places who visit us here. The stay is good for your health, but I will have Christmas at home. Asle, my husband, must also return to fishing in April." During the 1990s about $10 \%$ of the population, or four to six families, travelled away during the winter. As they grow older, or as spouses die, this form of mobility practice may change. Solrun and Asle still went to the south of Europe in 2016, but they did not stay as long as they once did. Younger employed villagers take two to three week long holidays, and annually, about 10 to 20 women and men living in Skarsvåg gather at one of the Canary Islands at the same time.

Finally, since the local shop closed down in the 1990s, shoppingcommuting is another new mobility practice necessitated by having to obtain "everything from food to clothing and parts to the boat engine" from stores in the municipal centre or larger towns. Small stores in many fishing villages closed when big grocery chains expanded, causing centralisation of many retail services; the same is also the case for public services such as health services. Such changes imply more travelling. In previous times, doctors and nurses used to travel to villages once or twice a month, but many municipalities, like Nordkapp municipality, no long provide that type of services, so patients travel to them. The health staff argues that they can give better service in their offices. Such changes took place after New Public Management principles were introduced as leading principles in the municipal economy.

\footnotetext{
${ }^{8}$ Fieldwork in the municipality of Loppa 2014
} 


\section{New Trends of Immigration from Abroad}

When the filleting factories started and developed after World War II, young women and men from places in Norway with scarce employment for women and from Finland and many years later from Sri Lanka found filleting work at the fish plants, for example in Hammerfest, Kjøllefjord, Mehamn, Båtsfjord, Berlevåg, and Vardø (Brox 1966; Bersvendsen 1998; Høgmo 1998). When the filleting factory started in Skarsvåg migrants also arrived. Especially in the summertime (Gerrard 1975). Some stayed for a period, some married, and many left.

In the 1990s fish plants in Båtsfjord hired Russian workers through special arrangements (Aure 2008). Because of the quota system and the changes in the production system, when the filleting of fish took place in China, the number of national and international workers was reduced. In this way, even a little fishing village like Skarsvåg has a history of migrant workers. When countries from the former Eastern Europe entered the EU and the EEA agreement come into work in 2004, immigrants from some of these countries came as workers seasonally at the fish plant while others baited long lines in organized baiting centres or for single boats or were hired by the owners of the fishing tourism firms. Now foreigners from the Nordic and EU countries also buy fishing boats and register as fishers.

In Skarsvåg, one couple from the Baltic area came to work at a fish plant, but when the industry dismissed the workers, they were hired to bait long lines for the fishers. After some years, the husband was recruited as a crewmember and registered fisher for one of the local boats. After some time, he got his own boat, and the couple bought their own house. The year after the school closed down the wife and the children went back to the couple's home country. The husband now returns during the less busy seasons or when one of his children is ill. The wife have also returned to Skarsvåg to help her husband fish while her mother took care of her children in their home country. In the winter season of 2015, they hired another woman from their country who lived with them and took care of the youngest children while the couple went fishing. The wife's father and sister have also come along as seasonal workers at the fish plant when needed. All have stayed together in the couple's house. In this way, they commute between the fishing village and their home country. At the same time, the male partner maintains Norway as his formal place of residence in order to be licensed to fish as a professional and registered fisher.

Another couple and their adult children emigrated to Skarsvåg from another of the new EU countries. The husband came as a manager of the fish-tourism company owned by fellow-countrymen. After a while, he 
rented a little boat and registered as a fisher. Until recently, each member of the family bought a small boat and were registered fishers. Single men and women have also arrived, bought houses and established businesses in construction, tourism, and fisheries. As one of them explained, "I really feel at home in Skarsvåg. Even though the climate is cold and the fishing is hard, this is a good place to live. Because of my health conditions I might stay in my house in the South of Europe during the winter." Recently he married a woman from the municipal centre and moved, but commutes to his professional activities in Skarsvåg.

Among immigrants in Finnmark, women from Asia, Russia, and other countries have married men from fishing societies (Munkejord 2009, 2011). Some of them have lived in Skarsvåg for a period, but some migrate with their husbands to other locations in Norway. While they lived in Skarsvåg, the immigrants, independent of where they came from, travelled to their original homes frequently to visit family and friends. This form of living us called circular migration, enabling the migrants to maintain regular contact with their original homes and families (Constant and Zimmerman 2011).

In a fishery village like Skarsvåg, some of the fishing tourists from other countries in Europe literally commute, coming year after year and several times every year. Fishing tourist companies owned by foreigners seem to recruit customers mainly from their home countries, and many who fish all day long every day for a week so they can take large boxes of filleted fish to their home countries. Compared with other types of migrating groups, these fishing tourists have little or no contact with the local community and do not participate in the local life.

These examples of the fishers, the fisher's wives or partners, as well as women and men from abroad, illustrate that different forms of mobility practices are intertwined and even circular in their character. Some practises are widespread, but serve diverse purposes such as work, shopping, education, health services, leisure, or family continuity. Others are more seasonal, like the Sami reindeer herders, fishers from other areas, and seasonal workers.

Women and men's mobility practices are many and vary by job, age, health conditions, nationality, family and friendships. When the migrated women and men born in Skarsvåg return to their parents' houses for the holidays or participation in festivals or special occasions, the fishing villages become a common meeting place for community or family reunions as well as for locals and well-established foreigners. Still, mobility practices appear to remain gendered because men engage in fishing mobility both for purposes of leisure and as a fishing professional. Among established couples, middle age, and elderly women support the idea of moving away (Gerrard 2013). Both women and men commute, and Norwegians, Sami 
reindeer owners, and women and men from abroad all practice circular migration for different reasons.

The examples from Skarsvåg give an understanding of the various practices of mobilities. These practices are related to national and international agreements like the quota system, the EEA agreement, new standards as well as new principles for the municipal budget and longer compulsory schooling. However, material conditions like fish resources, boats, and buildings are also important, as are structural conditions like the organization of various forms of work. Such circumstances are also connected to cultural understandings, values, and knowledge of women's and men's work and travelling, including women's locational wishes.

\section{Changing Mobility Practices and Gender Contracts}

Changing mobility practices also have impact on the gender contracts. Since women now play significant roles in deciding where and when couples or families will settle or resettle, the patrilocal settlement pattern is changed to a unilocal pattern. Wives and female partners in agreement with their husbands or male partners choose to move to a town or a centre and seem to have a desire for wellbeing, proximity to a job that might not exist in a fishing village, but also proximity to schools in order to avoid commuting for their children when they go to school. Desires for a life outside the fishing village may be based on their own experiences, but also on the expectations or future thoughts about the fishing village's development in relation to their own and their children's needs. As local job options for women have diminished or disappeared, migration for the family and commuting for the husband are considered as possible solutions enabling both partners to maintain incomes. However, husbands usually continue as the main breadwinner of the family. ${ }^{9}$ But women's own paid work and wishes in relation to where the men in their lives work seem to play just as an important role. New settlement choices demonstrate new agreements between partners, and in today's situation, the contract terms are more diverse and more complex, enabling both men and women to realize personal goals and goals for their families in relation to employment and accessing other resources. The difference now is that men are not only mobile at sea, but also on land. In the cases where the family settles far away from the fishing village, both must accept longer separations and digital contact. This is not new in itself, but the greater distances commuted on land by the fishers born in Skarsvåg is new.

Also new is that several Skarsvåg women have become registered in the National Register of Fishers since the quota system was introduced. One of

\footnotetext{
${ }^{9}$ Tax rolls for fisher families before and after the emigration.
} 
them fished with her husband; she was one of the first women to practice fishing as a registered fisher in Skarsvåg and thus performed mobile work at sea. The others carried out fishing related work on shore as they always had done. Earlier, registration for women had not been so easy (MunkMadsen 1996). Neither women nor men thought of women's fishery related work on land as fishing although men doing the same were registered as fishers (Gerrard 1975). In the new situation, the most active couples obviously came to an agreement that it was important to register. One of the reasons for this was that the economy of the household was better when the fisher did not need to hire people outside his household. In some cases, wives with long experience in baiting also did more of the work than men had done earlier. At the same time, fishery administration recognized women's fishing related work with the result that women were registered. Foreign-born immigrant couples without much experience in fishing some years later come to an agreement of how they want to organize their fishing. These cases demonstrate that a new system decided upon from outside combined with new agreements among the fisher and his wife can lead to new practices and new agreements and thus to new gender contracts.

The new kind of gender contracts can also be found among the elderly couples going to the Mediterranean area regularly in the winter months and to cabins in the summer months. In many of these cases, the wives' wishes for a "sunny winter" are fulfilled, but under conditions that they return in due time for the husband, the fisher, to be able to fish during the spring season that he considered to be the best and more suitable for an elderly fisher. This was the case with Solrun and Asle. Similarly, the way the couple with small children from the Baltic area practice circular migration, coming to Norway and going back to their home country, can also be understood in the light of new gender contracts within the coastal fishing village. Obviously, they came to an agreement to settle in Skarsvåg, when they bought a house, a boat, and the husband registered as a fisher, but agreed that the wife would move back to her country and to her relatives. The husband would visit the family when one of the children was hospitalized and during holidays. They created their own unique contract consisting of many complex elements to meet their own needs.

The changes of mobility practices of fishing villages have taken place and become more diverse. Such changes can be understood in the light of the changes of the local gender contracts where the women's motives have greater weight than they did before, especially when work and settlementrelated questions count. Gender contracts are connected to new mobility practices in the form of new travel patterns, better economy, better communications and changes in the households' social organization. They create new experiences and new knowledge. In this way, juridical, material, 
structural, and cultural elements are intertwined in the negotiation of flexible new relationships and contracts. How the couples form their contracts seem therefore to be influenced by the intersection between gender, class, ethnicity, nationality and age.

\section{Conclusion: Flexible, Diverse, and Multicultural Gender Contracts}

What type of knowledge has this discussion focusing on the relationships between mobility practices and gender contracts enhanced? One thing is clear: When mobility practices change, the terms of gender contracts also change.

Gendered division of labour and gendered mobility practices still exist. Young women continue to move away, but now elderly women, young as well as elderly men also represent larger groups of emigrants. It is no longer only men and men's employment that seem to influence the gender contracts related to a household's settlement and decisions of where to live. Patrilocal settlement principles have changed into unilocal settlement principles. Couples settle in places that benefit both parties, and both parties agree. Mobile practices from small fishing villages do not only include work and education related mobilities, but also mobility practices like shopping, medical service, vacation, and leisure, and commuting, representing relatively new gendered practices. Behind such patterns one can find new as well as steadily repeated gender contracts.

Returning to Ina and her family, I met her again in July 2015 when she together with other young and middle age migrants and inhabitants in Skarsvåg was one of the active committee members arranging Verdens nordligste bryggefestival in Skarsvåg. She had also visited Skarsvåg some years before when the family gathered for a big family reunion where her twins were baptized and her relatives celebrated important anniversaries. In 2015, she came with her twins, now young schoolgirls, while her husband stayed home to care for the youngest. Ina's case, but also all the other emigrants coming home for various reasons, illustrate how the fishing village has become a place for leisure, family reunion, and holidays as a contrast to their everyday working life in other parts of the country. These examples also show women's influence on family affairs and holiday mobility. In this way the emigrated women and men and their families confirm their belonging and may even strengthen the identity to their place of birth, elements that also seem important in gender contracts. Activities like participating in local festivals may also be interpreted as a continuous and long-lasting identification with a specific place, in this case Skarsvåg. 
For those who still remain in the fishing village, the village becomes a place where work is performed, but also a place where they keep the houses, the social infrastructure and other important links so that emigrants can return, like in Ina's case. The residents, on their side, leave in order to work and spend more of their holiday and leisure time in other places. Often such travels are because of women's wishes. These are also practices that can be observed among the immigrants from abroad. Both women and men seem to return to their home country in their leisure time and stay in Skarsvåg when they work. In this way women and men who have migrated from Skarsvåg together with some of the residents as well as the immigrants from the EEA countries can be said to practice circular migration and multiplace belonging.

All these processes create new gender relations and new gender contracts. The gender relations seem to have turned into more balanced and symmetric relationships with regard to where to reside, where to have a job that the women are educated for, and where children can attend school without commuting and stay away from home. The same can be said about where to go for holidays and where and when to carry out many other everyday practices. Thus, gender contracts are more balanced, also for the residents who have lived in the villages for many years. This might be due to the way the household members succeed in creating a household organization that includes fishery work as well as work outside fisheries, leisure time activities and accept norms and cultural expressions coming from outside the fishing villages.

At the same time, it is within the fisheries that gender asymmetry is maintained. The quota system seems to have led to an even more maledominated industry with a sharper division between household activities and fishing boat activities, especially for the locals (Gerrard 2008, 2016). Fishery women and men are also embedded in national and international networks and agreements that have undergone major social changes. The fishermen's unions are still male dominated. Gender and women's rights are still seldom problematized and discussed in the fishery media, except in the silent summer months (FiskeribladetFiskaren $2013 \mathrm{a}$ and b). In fishing institutions, men and men's perspectives seem to maintain their power. There are still few female fishers, few female boat owners, and few women holding positions in fishers' unions (Gerrard 2016).

Gunnel Forsberg argued that women's and men's negotiations are important in order to understand what has been going on. Discussions and direct and indirect negotiations seem to have taken place more often in the fishing families than in the fishermen's associations, the Ministry of Fishery and Coastal Affairs, and the Directorate of Fishery. So far the foreign women and men have not engaged in the formal organized and institutional life of 
fishing. That can be one explanation of the way they are related to the fishing.

Within the same fishing village, I would therefore say that focusing on women's and men's mobility practices related to gender contracts opens up what we may call diverse, complex, multicultural gender contracts. Nevertheless, with several and varied gender contracts in which gender is intersected and intertwined with national, ethnic, age related, and multicultural aspects, it might also be more difficult to speak about common and local-based gender contracts.

What is interesting is that mobility practices and new gender contracts also seem to have brought changes in the local fishery culture. The Norwegian fishery literature from the1970s focused on strong interdependencies between the fishing boat, the household, the processing plants, and cultural institutions such as schools (Wadel 1980; Gerrard 1983). Today, when household members establish themselves other than where the boat is moored, the relationships between the boat, a specific fish plant, and the household are "broken." When the fisher family moves away, they might also settle in neighbourhoods where there are few other fisher families and thus represent a minority in their neighbourhood.

When the important link between settlement and work is weakened, an important prerequisite for coastal fisheries culture based on the fishers and the families living nearby the fishing grounds has changed. This may be understood in relation to economic and political processes also taken place outside the fishing villages. Privatization of fishing rights in the form of quotas, but also new technology, fishers from abroad, and increased market orientation by fishers constitute different frameworks for the fisher populations' actions and thus for gender contracts. One can also observe the increased demands for flexibility between the spouses as they face greater variation in organization of daily life compared with earlier years. Nevertheless, men's higher incomes and greater wealth, which still form the core of the household's economic support, seem to maintain a gender asymmetry in income that the spouses silently agree upon. This is the case whether the household still resides in a small fishing village, in towns, or centres, and whether the male and female household members come from Norway or from the other countries.

\section{Acknowledgements}

First of all, I will thank the residents of the fishery villages, especially the population of Skarsvåg, as well as my colleagues at the Center for Women and Gender Research at UiT The Arctic University of Norway. Without their 
experience and inspiration, I would never have been able to write this article.

The editors of this special issue have given valuable advices through a long revision and writing process. I will also thank Kathleen Lahey at Queen's University, Canada, and her staff for their important academic and language assistance. Since this article builds on earlier contributions (Gerrard 2011, 2015), I will also thank the publishers and editors, Universitetsforlaget and Hilde Danielsen, and Orient BlackSwan and Marylin Porter and Subhadra Mitra Channa.

\section{Funding}

The Norwegian Research Council: The RAMBU program and the project: Sustainable coastal culture. A gender perspective on resource management and area use (Project number 152404).

The Norwegian Research Council: The program for basic research and the project: Mobile Lifestyles Perspectives on Work Mobilities and Gender in the High North (Project number 214265).

\section{References}

Arctic University of Norway. (no date). Mobile Lifestyles: Perspectives on Work Mobilities and Gender in the High North. https://uit.no/prosjekter/prosjekt?p_document_id=356461 (Accessed 2017-05-02)

Aure, Marit. 2008 Arbeidsmigrasjon fra Teriberka til Båtsfjord 1999-2003. Dr.polit. diss. University of Tromsø.

Bersvendsen, Hilde. 1998. Flerkulturelt arbeidsmiljø: «kem e det som skal tilpasse sæ, vi eller dem?» En sosialantropologisk studie. Master Thesis. Department of Social Anthropology, University of Bergen.

Bratrein, Håvard Dahl. 1975. Det tradisjonelle kjønnsrollemønster i NordNorge. In Forfatterkollektiv. Drivandes kvinnfolk. Om kvinner, lønn og arbeid. Tromsø: Universitetsforlaget, 21-38.

Brockman, Grete and Kjeldstadli, Knut (eds.). 2008. A history of immigration the case of Norway 900 -2000. Oslo: Universitetsforlaget.

Brox, Ottar. 1966. Hva skjer i Nord-Norge. Oslo: Pax forlag.

Constant, Amelie F. and Zimmermann, Klaus F. 2011. Circular and Repeat Migration: Counts of Exits and Years Away from the Host Country. Population Research and Policy Review 30 (4): 495-515.

Crenshaw, Kimberly. 1989. Demarginalizing the Intersection of Race and Sex: A Black Feminist Critique of Antidiscrimination Doctrine, Feminist 
Theory and Antiracist Politics. The University of Chicago Legal Forum (140): 139-167.

Davis, Donna Lee and Nadel Klein, Jane (eds.). 1988. To work and to weep: Women in Fishing Economics. St. John's: ISER, Memorial University of Newfoundland.

EFTA. 2015. EEA Agreement. http://www.efta.int/eea/eea-agreement (Accessed 2015-08-31).

Engebrigtsen, Ada and Norbert, Elias. 2006. Makt, skam og sivilisering: somaliere i eksil og det norske samfunnet. Tidsskrift for samfunnsforskning 31 (1): 109-123.

FiskeribladetFiskaren. 2013a. Ungdomsfiskeordninga - også for jenter. FiskeribladetFiskaren. 5 July.

FiskeribladetFiskaren. 2013b. Naturstridig kjønnskvotering. FiskeribladetFiskaren. 13 July.

Flakstad, Anne Grethe. 1984. Kan endring innen kvinnearbeidet utløse strukturendringer? In Ingrid Rudie (ed.). Myk start - hard landing. Om forvaltning av kjønnsidentitet i en endringsprosess. Oslo: Universitetsforlaget, 64-83.

Foss, Olaf. 2009. Life-course migration in coastal communities - Norway. Many locals leave, few newcomers stay for long. http://norafo.typo3cms.dk/fileadmin/user_upload/files/72/200910301519 41512.pdf (Accessed 2017-05-02).

Forsberg, Gunnel. 2001. The difference that space makes. A way to describe the construction of local and regional gender contracts. Norsk Geografisk Tidsskrift 55 (3): 161-165.

Friedman, Susan S. 1998. Mappings: feminism and the cultural geographies encounter. Princeton: Princeton University Press.

Gerrard, Siri. 1975. Arbeidsliv og lokalsamfunn. Mag.art. diss. Department of Social Science, University of Tromsø.

Gerrard, Siri. 1983. Kvinner i fiskeridistrikter - fiskerinæringens bakkemannskap. In Bjørn Hersoug (ed.). Kan fiskerinæringen styres? Oslo: Novus Forlag, 217-241.

Gerrard, Siri. 1986. Kvinners makt og avmakt. Et kjønnsrolleperspektiv på forvaltning av faglige interesser i fiskeindustrien. Fdh-rapport 6. Alta: Finnmark distriktshøgskole.

Gerrard, Siri. 1995. When women take the Lead: Changing Conditions for Women's Activities, Roles and Knowledge in Northern Norway's Fishing Communities. Social Science Information 34, (4): 595-631.

Gerrard, Siri. 2003. Må det bo folk i husan. In Marit S. Haugen and Egil Petter Stræte (eds.). Ut i verden og inn i bygda. Trondheim: Tapir akademiske forlag, 143-157. 
Gerrard, Siri. 2008. A Travelling fishing village: the specific conjunctions of place. In Jørgen Ole Bærenholdt and Brynhild Granås (eds.). Mobility and Place: Enacting Northern European Peripheries. Aldershot: Ashgate, 7586.

Gerrard, Siri. 2009. Fra fiskevær til ferievær? Om kystsamfunn i endring. In Einar Niemi and Christine Smith-Simonsen. Det hjemlige og det globale. Festskrift til Randi Rønning Balsvik. Oslo: Akademisk publisering A/S, 386-399.

Gerrard, Siri. 2011. Mobile praksiser og kjønnskontrakter i fiskerisamfunn. Tidsskrift for Kjønnsforskning 35 (1): 41-56.

Gerrard, Siri. 2013. Mobilities, Materialities and Masculinities: Interconnected Mobility Practices in Norwegian Coastal Fisheries. Norsk Geografisk Tidsskrift-Norwegian Journal of Geography 67 (5): 312-319. http://dx.doi.org/10.1080/00291951.2013.847482

Gerrard, Siri. 2015. Mobility Practices and Gender Contracts in a FisheryRelated Area. In Subhadra Mitra Channa and Mailyn Porter (eds.). Gender, Livelihood and Environment: How women manage resources. New Dehli, India: Orient BlackSwan, 113-140.

Gerrard, Siri. 2016. Kvinner i kystfiske, gjester ved menns bord. In Mari Teigen and Sigtona Halrynjo (eds.). Ulik likestilling $i$ arbeidslivet. Oslo: Gyldendal Akademisk, 277-298.

Gerrard, Siri and Balsvik, Randi Rønning (eds.). 1999. Global Coasts. Life Changes, Gender Challenges. Kvinnforsks skriftserie 2/1999.

Haavind, Hanne. 1977. Den usynlige makten. KjerringRåd (3): 14-21.

Haavind, Hanne. 1994. Kjønn i forandring - som fenomen og forståelsesmåte. Tidsskrift for Norsk Psykologiforening 31 (9): 767-783.

Hansen, Tore. 2014. New Public Management. Store norske leksikon. https://snl.no/New_Public_Management (Accessed 2017-04-25).

Hirdman, Yvonne. 1988. Genussystemet - reflexioner kring kvinnors sociala underordning. Kvinnovetenskaplig Tidskrift (3): 49-63.

Hjorthol, Randi. 2008. Daily mobility of men and men - a barometer of gender equality? In Tanu Priya Uteng and Tim Cresswell (eds.). Gendered Mobilities, Aldershot: Ashgate, 193-209.

Høgmo, Asle. 1998. Fremmed i det norske hus: Innvandreres møte med bygdesamfunn, småby og storby. Oslo: Ad Notam/Gyldendal.

Kuhnle, Stein. 1983. Velferdsstatens utvikling: Norge i komparativt perspektiv. Oslo: Universitetsforlaget.

Langørgen, Audun. 2007. Sentralisering - årsaker, virkninger og politikk». Samfunnsspeilet 21 (2): 46-59.

Levin, Irene. 2004. Living Apart Together. Current Sociology 52 (2): 223-240.

Lykke, Nina. 2003. Intersektionalitet - ett användbart begrepp för genusforskningen? Kvinnovetenskaplig tidskrift 2003 (1): 47-57. 
Munkejord, Mai Camilla. 2009. Hjemme i nord: En analyse av stedsopplevelser med utgangspunkt i kvinnelige og mannlige innflytteres fortellinger om hverdagslig i Havøysund og Vadsø, Finnmark. Ph.d. diss. University of Tromsø.

Munkejord, Mai Camilla. 2011. Hjemme i nord: om bolyst og hverdagsliv blant innflyttere i Finnmark. Stamsund: Orkana forlag.

Munk-Madsen, Eva. 1996. Fiskerkøn. Ph.D. diss. Norges fiskerihøgskole, University of Tromsø.

Neis, Barbara. 1993. From 'Shipped Girls' to 'Brides of State': The Transition from Familial to Social Patriarchy in the Newfoundland Fishing Industry. Canadian Journal of Regional Science 16 (2): 185-211.

Neis, Barbara, Binkley, Marian, Gerrard, Siri and Maneschey, Maria Cristina (eds.). 2005. Changing Tides: Gender, Fisheries and Globalization. Black Point, Nova Scotia: Fernwood Publishing.

NOKUT. (no date). General information about education in Norway. http://www.nokut.no/en/Facts-and-statistics/The-NorwegianEducational-System/education-in-norway/ (Accessed 2016-07-13).

Nordstrøm, Johan. 2016. Røkkes Aker selger hele fiskeimperiet. Dagens Næringsliv. 2 June.

Nyseth, Torill. 1983. Det blei nu bærre sånn»: om ungdom og valgsituasjoner belyst ved en studie av et ungdomskull $i$ Hammerfest. Master theses. Department of Social Sciences, University of Tromsø.

On the Move Partnership. No date. www.onthemovepartnership.ca (Accessed 29.5.2017).

Porter, Marilyn. 1993. Place and persistence in the lives of Newfoundland women. Aldershot: Avebury.

Rudie, Ingrid. 1969/70. Household Organization: Adaptive Processes and Restrictive Form. A viewpoint on economic change. Folk (11-12): 185-200.

Rudie, Ingrid. 1984. Innledning. In Ingrid Rudie (ed.). Myk start - hard landing. Oslo: Universitetsforlaget, 13-36.

Rudie, Ingrid. 2008. Tid, rom, praksis og erfaring. Noen analytiske refleksjoner. Eresforelesning, Norsk antropologisk forenings årskonferanse, 4. mai 2007. Norsk Antropologisk Tidsskrift 2-3: 80-93.

Sandanger, Solveig. 1979. Tromsøs pendlingsomland. Tromsø: Department of Social Science, University of Tromsø.

Statistisk Sentralbyrå. 1981. Folke-og boligtelling 1980. Kommunehefte. http://www.ssb.no/a/folketellinger/kommunehefter/1980/ (Accessed 2017-05-02).

Statistisk Sentralbyrå. 1991. Folke-og boligtelling 1990. Kommunehefte. http://www.ssb.no/a/folketellinger/kommunehefter/1990/ (Accessed 2017-05-02). 
Sørlie, Kjetil. 2005. Upubliserte tabeller. SSBs flyttehistoriemateriale. Oslo: NIBR.

Utsi, Marit Meløy. 2010. Mellom kultur og økonomi. Reindrift og kvinners hverdagsliv. Master thesis. Department of Social Sciences, University of Tromsø.

Wadel, Cato. 1980. Lokalsamfunn, hushold og bedrift: Noen aktuelle næringspolitiske koordineringsproblemer i kyst-Norge. In Iens Ludvig Høst and Cato Wadel (eds.). Fiske og lokalsamfunn. Tromsø: Universitetsforlaget.

Walsh, Deatra. 2016. Going the distance? Gender and commuting in Northern Norway. Paper delivered at Gender and (Im)mobilities in the Context of Work - an international interdisciplinary conference, Tromsø: June $15-17,2016$.

\section{Notes on contributor}

Siri Gerrard's research interests are related to fishing, fishery-plant work, fishery villages and fishery cultures. Most of her contributions focus on women and gender relations in various contexts and situations. Analytically she builds on and develops interdisciplinary gender perspectives. Her main method is participant observation. The research has taken place in coastal area since the 1970s, mostly in Finnmark, Northern Norway. She has written chapters in books, articles in feminist journals and been a co-editor of several books. 